\title{
Juventude e Práticas Artísticas e Culturais nas Metrópoles
}

proposta deste dossiê é tratar de questões relativas ao contexto das grandes metrópoles

$\mathrm{A}_{\text {mundiais as quais registram nos espaços urbanos um conjunto de inscrições }}$ produzidas por indivíduos e grupos juvenis. São sinais, vestígios e marcas, de longa ou curta duração que utilizam prioritariamente a linguagem artística como expressão. As ruas, praças, muros e o próprio corpo dos jovens são amiúde utilizados como suportes de uma comunicação que se realiza por meio de símbolos gráficos, imagens e sons. As intervenções artísticas se contrapõem à segregação socioespacial, violência, racismo, individualismo, exclusão social que vêm promovendo o esvaziamento da vida pública, instalando medo e ritos de suspeição em relação aos excluídos. Por meio de performances artísticas os jovens se propõem a ocupar as ruas e praças, enriquecendo-as com cores e tintas, sobrepondo tonalidades e sonoridades que reinventam a paisagem urbana.

As intervenções artísticas juvenis, embora, assumam por vezes caráter autoral, individual, podem resultar também de ações coletivas. As turmas, gangues, galeras, crewss, posses, equipes de baile, grupos teatrais, cooperativa de escritores, revelam uma dimensão do comportamento juvenil de natureza gregária, em que se valoriza a pertença ao grupo e circunscrevem identidades. Não há paralelo nesse caso com o experimento do urbano enquanto estilo de vida, marcado pelo ar blasé, pela postura defensiva, indiferente, identificado nos estudos pioneiros sobre as metrópoles. Ao contrário do anonimato e do distanciamento, deseja-se visibilidade, interação, participação, coletividade, calor humano.

A arte situada ao nível das práticas juvenis estabelece, nesse sentido, uma ruptura importante com a tradição ocidental. Nesta esfera a produção artística sempre esteve associada à noção de objeto canônico, a ser contemplado à distância, por meio da admiração circunspecta, por isso mesmo o isolamento imaculado nas Grandes Galerias. A práxis artística juvenil, ao contrário, encontra-se nas ruas. Intencionalmente se coloca como provocação cotidiana aos sentidos, ao olhar e aos ouvidos do cidadão comum. Há nessa proposta uma firme intenção em intervir na paisagem urbana. Em desnaturalizar o edificado e, promover o estranhamento, romper com a aceitação passiva da ordem estabelecida. A arte que se encontra inscrita nas praças, becos, vielas, casas noturnas, bares, túneis, muros e postes, é de natureza fugaz, profana, não se importando em ser profanada, em permanecer desprotegida, desabrigada, sujeita à ação de pessoas e ao 
tempo, porque deseja exprimir-se momentaneamente, manifestar inconformismo, engajamento e protesto.

As intervenções artísticas juvenis não se realizam, porém, enquanto experimentos isolados da ordem social mais ampla. Podem ser elaboradas tanto no circuito underground como prática contradiscursiva, como inscrever-se na esfera do mercado de bens simbólicos. Surgem nesses casos tensões peculiares à apropriação da arte enquanto mercadoria. Quando, por exemplo, os grafiteiros deixam as ruas e adentram as Galerias de Arte, bandas de garagem, grupos de rap, punk, funk, kuduro alcançam sucesso fonográfico, escritores marginais passam a ter os livros publicados por grandes editoras, o circuito underground se rompe e o acesso à produção artística se amplia. Diferentes questões, porém, se colocam nesse momento para os artistas e a obra de arte. A fidelização ao grupo, às comunidades locais, a redução do potencial contradiscursivo, especialmente quando o controle do fazer artístico por eles mesmos lhes escapa.

As práticas culturais juvenis orientadas para o fazer artístico têm colocado, portanto, questões relevantes não apenas para a compreensão de um grupo etário específico, mas para o entendimento de uma série de problemas emergentes nas grandes metrópoles. Diferentes áreas do conhecimento vêm se ocupando do fenômeno e as interpretações não são necessariamente convergentes. As pesquisas que incorporam o ponto de vista dos jovens sobre os usos e sentidos das intervenções, recuperam também registros iconográficos, discursos, imagens e sons. As Ciências Sociais, Escolas de Artes, Letras e os diferentes subcampos de investigação como Antropologia Urbana, Antropologia Visual, Artes Plásticas, Etnomusicologia, Antropologia da Perfomance, entre outras, vêm contribuindo com diferentes perspectivas de análise.

A organização do Dossiê se apresenta como uma iniciativa que visa ampliar o debate entre pesquisadores situados em diferentes contextos. Trata-se também de uma oportunidade rara para a publicização de dados etnográficos, explicitação de premissas teóricas, categorias conceituais e metodologias de pesquisa. Sabemos que os novos processos de segregação urbana, as novas mídias, a internacionalização da cultura têm deslocado as tradicionais formas de constituição das identidades de indivíduos e grupos nas metrópoles. As respostas que os segmentos sociais juvenis apresentam se sustentam em grande medida no fazer artístico. Os artigos que configuram o dossiê nos ajudam a fazer esse movimento.

Inicialmente, apresentamos o artigo de Ana Maria Niemeyer, "Caldeirão da injustiça”, que discute um projeto antropológico que pesquisou o preconceito, a discriminação e o racismo no quotidiano escolar, trabalhando com adolescentes e jovens, alunos de duas escolas públicas de bairros pobres da Zonal sul de São Paulo. Nessa pesquisa expressões e criações artísticas desses jovens como histórias em quadrinhos e letras de rap foram valorizadas como forma de construir o dialogo etnográfico, mas também como narrativas sobre o vivido que se transformaram em dados fundamentais para a pesquisa.

Em seguida trazemos o artigo de José Carlos Gomes da Silva, "Do Hip-Hop ao Sarau Vila Fundão: jovens, música e poesia na cidade de São Paulo" que focaliza os nexos entre duas práticas culturais juvenis expressivas na cidade de São Paulo, o movimento hip-hop e os saraus literários. A hipótese defendida no artigo é que tanto um como o outro, embora guardem suas especificidades, compartilham de uma mesma postura crítica sobre a segregação urbana, protestam contra a violência que atinge os jovens, questionam as violações aos direitos humanos, denunciam o racismo e promovem intervenções que têm como suporte a linguagem artística. 
A discussão sobre a retomada do espaço público como espaço da política cotidiana realizada por José Carlos nos leva, então, à discussão sobre as formas de apropriação desse mesmo espaço público e de seu corpo, no caso a cidade, como um lugar da disputa de histórias e memórias, tema desenvolvido por Alexandre Barbosa no artigo "Quem não é visto não é lembrado". Nesse artigo, o autor analisa o modo como a "pixação" na cidade São Paulo, protagonizada por jovens dos bairros da periferia, configura um dispositivo de sociabilidade, reconhecimento e memória. A "pixação" configura, assim, uma escrita peculiar que esses jovens gravam na paisagem urbana e que faz sentido principalmente para eles, que sabem ler os muros. Por meio dessa escrita, eles criam referências próprias no espaço urbano e recriam a cidade, mesmo que em contraposição à maioria da população, que "não vê com bons olhos" sua atividade.

De São Paulo partimos para uma análise comparativa com Lisboa realizada por Rosana Aparecida Martins em seu artigo "Representação e sentido de pertencimento dos hip hoppers em São Paulo e Lisboa" que toma as associações juvenis na contemporaneidade como ponto de partida, e discute a cena urbana atual e as políticas públicas dirigidas aos jovens, através da dinâmica de comunicação marcado por membros da Zulu Nation Portugal (Lisboa, Portugal fundada por brasileiros) e Associação Posse Hausa (São Paulo, Brasil).

Já em Lisboa, passamos ao artigo "The return of performance" de Cláudia Guerra Madeira, de cunho mais teórico e histórico, que analisa alguns exemplos de expressões artísticas contemporâneas de intervenção na cidade que dialogam com as questões trazidas pela teoria da perfomance.

Por fim, e voltando a São Paulo, trazemos o ensaio fotográfico "Pimentas nos olhos não é refresco: Fotografia, espaço e memória na experiência vivida por jovens de um bairro "periférico" de Guarulhos, São Paulo”, de Andréa Barbosa que apresenta um recorte de fotografias, de vários autores, produzidas dentro de um projeto de pesquisa etnográfica que se propõe a realizar uma reflexão acerca dos fluxos de identidade, memória e experiência construídos por um grupo de jovens do e no Bairro dos Pimentas em Guarulhos, São Paulo. Nessas fotografias várias camadas se sentido se articulam e o ensaio propõe ao leitor, então, que espreite esses possíveis significados para fruir um Pimentas de imagens.

Os artigos reunidos nesse Dossiê sugerem, assim, diferentes possibilidades de análise das práticas artísticas juvenis. Todos abordam as intervenções estéticas a partir do domínio do fazer artístico dos jovens. Consideram as diferentes intervenções juvenis como modalidades distintas de representação do urbano. Identificam nas representações juvenis projetos e desejos de reinvenção da cidade em oposição à lógica da unicidade e controles instaurados pelo poder urbano. Questionam a concepção de arte como objeto autoral, imaculado e sigiloso, investido de valor econômico.

Os autores privilegiam nas análises a abordagem antropológica e suas diferentes possibilidades de compreensão das linguagens simbólicas.

Andréa Barbosa e José Carlos Gomes da Silva 